Article

\title{
A multi-Criteria Wetland Suitability Index for Restoration across Ontario's Mixedwood Plains
}

\author{
Sally J. Medland ${ }^{1}$, Richard R. Shaker ${ }^{1,2,3,4, * \mathbb{C}}$, K. Wayne Forsythe ${ }^{1,2,3}$, Brian R. Mackay ${ }^{2,3}$ \\ and Greg Rybarczyk ${ }^{5,6,7}$ \\ 1 Department of Geography \& Environmental Studies, Ryerson University, Toronto, ON M5B 2K3, Canada; \\ smedland@ryerson.ca (S.J.M.); forsythe@geography.ryerson.ca (K.W.F.) \\ 2 Graduate Programs in Environmental Applied Science \& Management, Ryerson University, \\ Toronto, ON M5B 2K3, Canada; brian.mackay@ryerson.ca \\ 3 Graduate Program in Spatial Analysis, Ryerson University, Toronto, ON M5B 2K3, Canada \\ 4 Department of Geography, University at Buffalo, Buffalo, NY 14261, USA \\ 5 University of Michigan-Flint, Flint, MI 48502, USA; grybar@umich.edu \\ 6 The Michigan Institute for Data Science (MIDAS), Ann Arbor, MI 48108, USA \\ 7 The Centre for Urban Design and Mental Health, London SW9 7QF, UK \\ * Correspondence: rshaker@ryerson.ca; Tel.: +1-416-979-5000
}

Received: 7 November 2020; Accepted: 24 November 2020; Published: 28 November 2020

\begin{abstract}
Significant wetland loss ( 72\%; 1.4 million hectares) in the Province of Ontario, Canada, has resulted in damage to important ecosystem services that mitigate the effects of global change. In response, major agencies have set goals to halt this loss and work to restore wetlands to varying degrees of function and area. To aid those agencies, this study was guided by four research questions: (i) Which physical and ecological landscape criteria represent high suitability for wetland reconstruction? (ii) Of common wetland suitability metrics, which are most important? (iii) Can a multi-criteria wetland suitability index (WSI) effectively locate high and low wetland suitability across the Ontario Mixedwood Plains Ecozone? (iv) How do best sites from the WSI compare and contrast to both inventories of presettlement wetlands and current existing wetlands? The WSI was created based on seven criteria, normalized from 0 (low suitability) to 10 (high suitability), and illustrated through a weighted composite raster. Using an Analytical Hierarchy Process (AHP) and importance determined from a scoping review of relevant literature, soil drainage had the greatest meaning and weight within the WSI (48.2\%). The Getis-Ord Gi* index charted statistically significant "hot spots" and "cold spots" of wetland suitability. Last, the overlay analysis revealed greater similarity between high suitability sites and presettlement wetlands supporting the severity of historic wetland cannibalization. In sum, this transferable modeling approach to regional wetland restoration provides a prioritization tool for improving ecological connectivity, services, and resilience.
\end{abstract}

Keywords: wetlands; multi-criteria evaluation; ecological restoration; analytical hierarchy process; landscape planning; land-use change; soil drainage; spatial analysis; scoping review; weighted index

\section{Introduction}

With growing intensity and speed, the Earth is undergoing a massive environmental transformation best described as global change [1,2]. Attributed to anthropogenic factors such as resource extraction, growing infrastructure footprint, and land conversion, global change can largely be summarized into two overarching categories: land-cover change and climate change [3-7]. The combination of climate change, land-cover change, and in turn, habitat loss, is largely understood to be a major driver in decreasing biodiversity worldwide [8-10]. Consequently, biodiversity is recognized as an 
endpoint indicator of biogeochemical and ecological integrity across scales [11-16]. Wetlands are one of the most biodiverse land-cover types on Earth and provide many ecosystem services that help to mitigate the effects of global change, including habitat, water quality improvement, nutrient cycling, recreation, groundwater recharge, and flood and erosion reduction [17-23]. Despite this, wetlands have often been converted in favor of development over other well-being needs and ecological services $[24,25]$. Their structure and area are impacted by land-cover change as a result of dredging and filling, eutrophication, alterations to hydrology, and surface runoff $[20,23,26,27]$. With approximately 150 million hectares of wetlands, Canada holds nearly one quarter of these important ecosystems-a combined area greater than any other country in the world [28,29]. In the Province of Ontario specifically, wetlands were historically regarded as muddy, impassable, useless terrain $[28,30]$. Unable to compete economically with other land uses, they were steadily replaced in favor of privatized and industrialized land $[20,27]$. As a result, when contrasting presettlement to 21st-century estimates, $72 \%$ (or 1.4 million hectares) of wetlands in Ontario have been eliminated by means of land-cover change, mostly to intensive agriculture [31,32].

The Ontario Ministry of Natural Resources and Forestry (OMNRF) [19] defined "wetland" as, "land that are seasonally or permanently covered by shallow water as well as land where the water table is close to or at the surface" (p. 2). "Wetland" can be viewed as a generic term for wet habitats organized within the five broad categories: bogs, wet meadows or fens, marshes, swamps, and shallow water, based on their dominating characteristics of vegetation (e.g., hydrophytes), soil (e.g., hydric soils), and terrain [20,33]. Once considered an obstacle to development, wetlands are now viewed as assets to the landscapes they occupy. The desirability has moved from the potential value of the space occupied by wetlands to what they provide in ecosystem services. In Ontario, wetland loss is concentrated in the Mixedwood Plains Ecozone, where population is highest and industry most abundant [19,32,34]. The disappearance of these valuable ecological assets has not gone unnoticed. Many major non-profit and government agencies have set goals to halt loss and work to restore wetlands to varying degrees of function and area [19,32]. Organizations such as Ducks Unlimited Canada (DUC), Environment and Climate Change Canada (ECCC), and the OMNRF have contributed research of this issue with a working goal to restore wetlands back to Ontario's landscape. Most recently, the OMNRF created the Wetland Conservation Strategy for Ontario 2017-2030 as a framework for wetland restoration in Ontario. The strategy involves two main goals: (i) By 2025, the net loss of wetland area and function is halted where wetland loss has been the greatest; and (ii) by 2030, a net gain in wetland area and function is achieved where wetland loss has been the greatest [19].

Advances in geographic information systems (GIS) have allowed researchers to better understand the spatial patterns of global change and how climate and land-use variations may impact the natural world [35]. In order to better plan for large-scale changes, GIS can be used to facilitate quick, replicable, quantitative decision-making tools. Coupled with GIS, multi-criteria evaluation (MCE) has historically shown promise for incorporating important, but oftentimes competing, variables for neighboring assessments [36] and sustainable development efforts across spatial scales [13]. Furthermore, GIS and MCE allow for smart allocation of sustainable development and reliance topics by considering many socioeconomic and ecological factors at once [13,37-41]. Relatedly, indices are recognized as useful tools for facilitating consistent quantitative decision-making over various spatial and temporal scales pertaining to resilience and sustainable development efforts $[12,17,42,43]$. They help to provide insight over a large-scale area, eliminating the need for project-by-project analysis [44]. Previously, multi-criteria indices and GIS have proven successful tools in identifying ideal wetland sites in other regions that have undergone wetland loss [24-26,44-48]. These combined tools may consider any biophysical or ecosystem service indicators, which represent best possible sites for wetland reconstruction [33]. However, few macroscale ecological studies have investigated the combined weighted importance of key wetland restoration variables to create a wetland suitability spatial decision-support tool. Even fewer studies have gone on to compare and contrast their suitability findings with existing and presettlement wetland datasets. 
Wetland loss in Ontario is the result of many small planning decisions in favor of agriculture, or industrial and residential development over these natural landscape features $[19,31,32,34]$. A larger-scale perspective of Ontario's wetland reconstruction potential could help to facilitate planning for wetland projects provincewide. Around the world, wetland indices have been used to assess wetland loss and understand where wetland restoration may be most valuable and viable; however, such an index does not yet exist for Southern Ontario. This research aims to create a multi-criteria index that prioritizes areas best suited for wetland reconstruction in Ontario's Mixedwood Plains. Therefore, to aid major agencies in their macroscale wetland restoration efforts, this study was guided by four research questions: (i) Which physical and ecological landscape criteria represent high suitability for wetland reconstruction? (ii) Of the common wetland suitability metrics, which are most important? (iii) Can a multi-criteria wetland suitability index (WSI) effectively locate high and low wetland suitability across the Ontario Mixedwood Plains Ecozone? (iv) How do best sites from the WSI compare and contrast to both inventories of presettlement wetlands and current existing wetlands? An overarching goal of this paper was to deliver landscape planners, ecological restoration scientists, regional planners, and environmental managers and decision-makers an applied example for systematically evaluating wetland suitability across space in temperate climate zones.

\section{Study Area}

The Mixedwood Plains Ecozone within the Province of Ontario defines the study area boundary for this research (Figure 1). For clarification, in 1976 the Canada Committee on Ecological Land Classification (CCELC) defined and delineated differing ecological (biophysical) areas into a multi-scale land management system based on abiotic and biotic characteristics [49]. This classification serves as a systematic resource for sustainable planning across Canada; ecozones are the largest of the environmental management classifications. This study area excludes the portion of the Ecozone crossing into Quebec and the Manitoulin Island region of Ontario, yet it is still viewed as one of the most valuable regions when considering its environmental and economic importance. Collectively, the entire Mixedwood Plains Ecozone makes up about 1.2\% of Canada's total landmass [34]; however this study's area equates to roughly $0.8 \%$ of Canada's governing territory. Specifically, $81,134 \mathrm{~km}^{2}$ $(68 \%)$ of the entire $118,870 \mathrm{~km}^{2}$ Mixedwood Plains Ecozone [34] is incorporated into this study. The Ecozone is bound between three Great Lakes: Erie, Huron, and Ontario. More precisely, it is located in Southern Ontario below the Hudson Bay Lowlands and Ontario Shield ecozones and spans across the southernmost regions of the province, including the St. Lawrence River Valley and the postglacial floodplains of the three aforementioned Laurentian Great Lakes [34,50]. The Ecozone is characterized by a temperate climate of warm summers and cool winters. The mostly glacial-shaped terrain is flat to gently rolling and includes an extensive network of waterways, surface and groundwater features, moraines, and the Niagara Escarpment [34,51]. Wetlands in the Ontario portion of the Mixedwood Plains are considered critically important landscape features, with six recognized as wetlands of international significance by the Ramsar Convention: Long Point National Wildlife Area, St. Clair National Wildlife Area, Point Pelee National Park, Mer Bleue Conservation Area, Matchedash Bay Provincial Wildlife Area, and Minesing Swamp [19]. Last, with wetlands playing a dominate role, the ecosystem goods and services provided by the Mixedwood Plains Ecozone have been conservatively estimated at $\$ 84$ billion (CAD) per year [34].

The Mixedwood Plains is the most populous and industrious ecozone in Canada; it is considered the second most fragmented ecozone in Canada [52]. Thirteen major urban areas are found within this ecozone, including the first, second, and fourth most populated Canadian cities of Toronto, Montreal, and Ottawa, respectively. Between 1971 and 2006, the human population of the Mixedwood Plains increased from approximately 11 million people to more than 16 million people; the rapid population growth was projected to increase by $30 \%$ by 2031 [53]. As a result, the Mixedwood Plains has seen the largest loss in wetlands, which in turn impacts the largest populations of Ontarians. Despite suffering a significant loss in wetland area (roughly $\sim 72 \%$ ) since presettlement, Ontario remains home to $6 \%$ of 
the Earth's total wetland area. For comparison, the conterminous United States has experienced an estimated loss of $53 \%$ of its presettlement wetlands, contributing to the large-scale erasure of wetlands and restoration needs in North America [54]. Specific to the Mixedwood Plains Ecozone, the wetland land cover classification was estimated at $25 \%$ of the total area presettlement and reduced to $7 \%$ by 2002 [32]. Wetlands have been expensed in favor of other types of land use due to poor management initiatives and small development decisions by various governmental bodies in order to accommodate the $92 \%$ of Ontarians (35\% of Canadians) and support industrial, residential, and agricultural needs over time [55]. This creates a necessity for more careful planning from large-scale perspectives in order to understand landscape composition and configuration, prevent habitat fragmentation, and restore larger wetland patches [44]. This phenomenon, in combination with the OMNRF goals to protect and restore Ontario's wetlands, make for an ideal study area for creating a multi-criteria wetland suitability index (WSI).

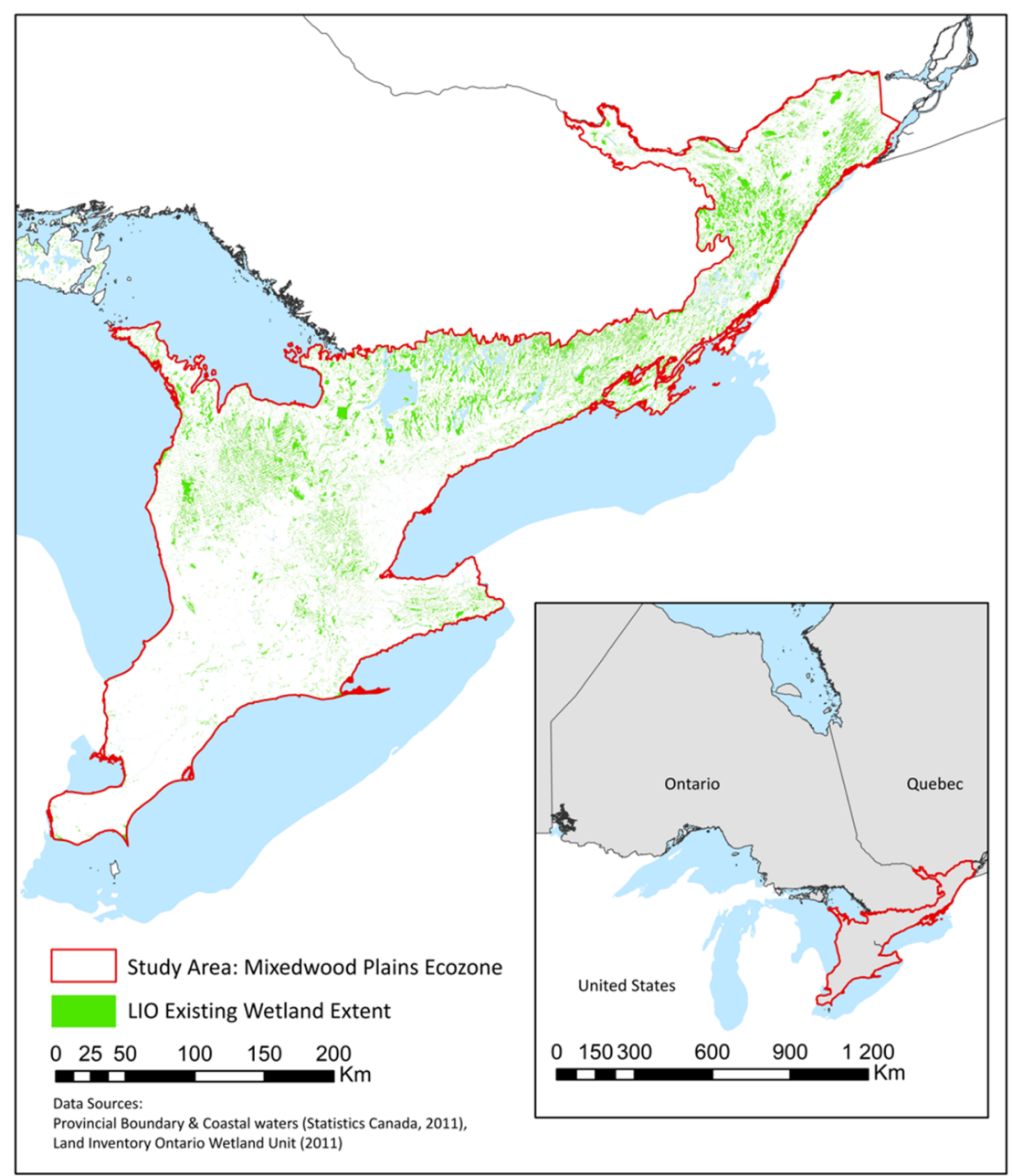

Figure 1. Study area map illustrating present wetlands within Ontario, Canada's Mixedwood Plains Ecozone.

\section{Materials and Methods}

\subsection{Data Preparation}

Criteria chosen for the wetland suitability index (WSI) included biophysical characteristics already present that would best support a wetland, land cover representing areas of need for wetland ecosystem services, and constraint variables. Biophysical variables present in similar wetland indices were selected, including soil drainage, groundwater level, slope, and proximity to streams $[18,20,24,31,33,45,46]$. In previous studies, ecosystem services were considered by incorporating areas of need such as 
agricultural land and frequently flooded areas to make best use of a wetland's flood mitigation and water filtration services $[25,27,46]$. Last, major waterbodies and built-up areas were included as obstacles to restoration in the index. In an effort to best model present conditions of the Mixedwood Plains landscape, the most current, complete, and highest possible resolution data were selected (Table 1).

Table 1. Data sources for input variables used in the wetland suitability index (WSI), and source information for the inventories of current existing wetlands and historic presettlement wetlands.

\begin{tabular}{cccc}
\hline Variable & Resolution & Source & Year \\
\hline Agriculture & $50 \mathrm{~m}$ & $\begin{array}{c}\text { Agricultural Resource Inventory (ARI)—Ontario } \\
\text { Ministry of Agriculture, Food, and Rural Affairs } \\
\text { Built-up Area_Ontario Ministry of Natural }\end{array}$ & $1983-2010$ \\
Built-up Area & $15 \mathrm{~m}$ & Resources (OMNR) & 2013 \\
Roads & $10-50 \mathrm{~m}$ & Major Roads Network-DMTI Spatial & 2018 \\
Groundwater & $\mathrm{N} / \mathrm{A}$ & $\begin{array}{c}\text { Provincial Groundwater Monitoring Network } \\
\text { (PGMN) - Ministry of Environment }\end{array}$ & 2016 \\
Major Waterbodies & $5-30 \mathrm{~m}$ & Waterbodies Region-DMTI Spatial & 2018 \\
DEM & $30 \mathrm{~m}$ & DEM90 Digital Elevation Model-EarthEnv & 2014 \\
Soil Type & $50 \mathrm{~m}$ & Canadian Land Inventory-Detailed Soil Survey & 2010 \\
Stream Network & $10 \mathrm{~m}$ & (DSS) Compilations & 2010 \\
Existing Wetland & Approx. $50 \mathrm{~m}$ & Wetland Unit-Land Information Ontario (LIO) & 2011 \\
DU 1800 Wetland & Variable & 1800 Presettlement wetland extent (c.1800)-Ducks & 2010 \\
\hline
\end{tabular}

A raster data type was chosen as the medium for calculating and illustrating the WSI. Raster data allow for pixel-by-pixel comparison within a landscape, allowing for finer resolution results when compared to vector boundaries. Each variable was resampled to $50 \mathrm{~m}$, because it was the lowest resolution of the input data (Table 2). This resolution was applied to all of the input data layers and provided the most detail without oversimplifying higher resolution data. For policy and planning purposes, using the finest resolution creates more spatially precise results that can later be aggregated and applied to different management scales [25]. All input layers were projected to the same georeferencing system to avoid any mismatch issues. In ESRI's [56] ArcMap 10.7, each variable was processed using Model Builder to ensure uniform parameters such as projection, snap raster, resolution, and pixel alignment. Within that geographic information systems (GIS) software, variables underwent differing geoprocessing to ensure they represented the intended goals (see Table 2).

Table 2. Selected data sources used in the wetland suitability index (WSI), intended goals of each, and pre-processing measures.

\begin{tabular}{|c|c|c|}
\hline Variable & Goal & Pre-Processing \\
\hline Agriculture & Prioritize conversion & $\begin{array}{l}\text { Clip, Select and Export Agriculture } \\
\text { only, Rasterize }\end{array}$ \\
\hline Built-up Area & Avoid & $\begin{array}{c}\text { Clip, Rasterize, Append "roads" } \\
\text { to "built-up" }\end{array}$ \\
\hline Road Network & Avoid & $\begin{array}{l}\text { Clip, Rasterize, Append "roads" } \\
\text { to "built-up" }\end{array}$ \\
\hline Soil Drainage & $\begin{array}{l}\text { Prioritize soils that are naturally more like } \\
\text { wetlands and avoid those with rapid drainage. } \\
\text { Prioritize areas that are prone to flooding }\end{array}$ & Clip, Rasterize, Aggregate Classes \\
\hline Groundwater Level & Prioritize shallow & Interpolate Surface (Kriging), Clip \\
\hline Slope & Prioritize gentler slopes & $\begin{array}{l}\text { Mosaic, Clip, Run Slope on DEM, } \\
\text { Aggregate Classes }\end{array}$ \\
\hline Stream Proximity & Prioritize closer proximity to streams & $\begin{array}{l}\text { Clip, Run } 250 \mathrm{~m} \text { and } 500 \mathrm{~m} \\
\text { buffers, Rasterize }\end{array}$ \\
\hline Major Waterbodies & Avoid major lakes and streams & Clip, Rasterize \\
\hline
\end{tabular}




\subsection{Suitablity Criteria and Normalization}

The WSI was created based on seven criteria, normalized from 0 (low suitability) to 10 (high suitability), and illustrated through a weighted composite raster (Figure 2). A 0-10 normalization allowed for the rescaling of data of different ranges, some of which could not be divided into equal numbers of classes due to the qualitative nature of certain data sources. The $0-10$ works well, as it is more likely to be universally recognized as a scale of quality. Additionally, it provides a larger and more gradual range of potential site suitability that makes best use of the fine raster resolution. Raster analysis allows for each grid cell to have an assigned value for each criterion. This simplistic method works for quantifying the cell's relative suitability for a wetland restoration/reconstruction project [44]. In the forthcoming section, weighting was determined by reviewing relevant literature on the applicable biophysical properties for wetland reconstruction $[18,25,44-46]$. The seven criteria variables-agriculture, built-up, soil drainage, groundwater, major water bodies, slope, and stream proximity-are further justified and explained in the next paragraph.

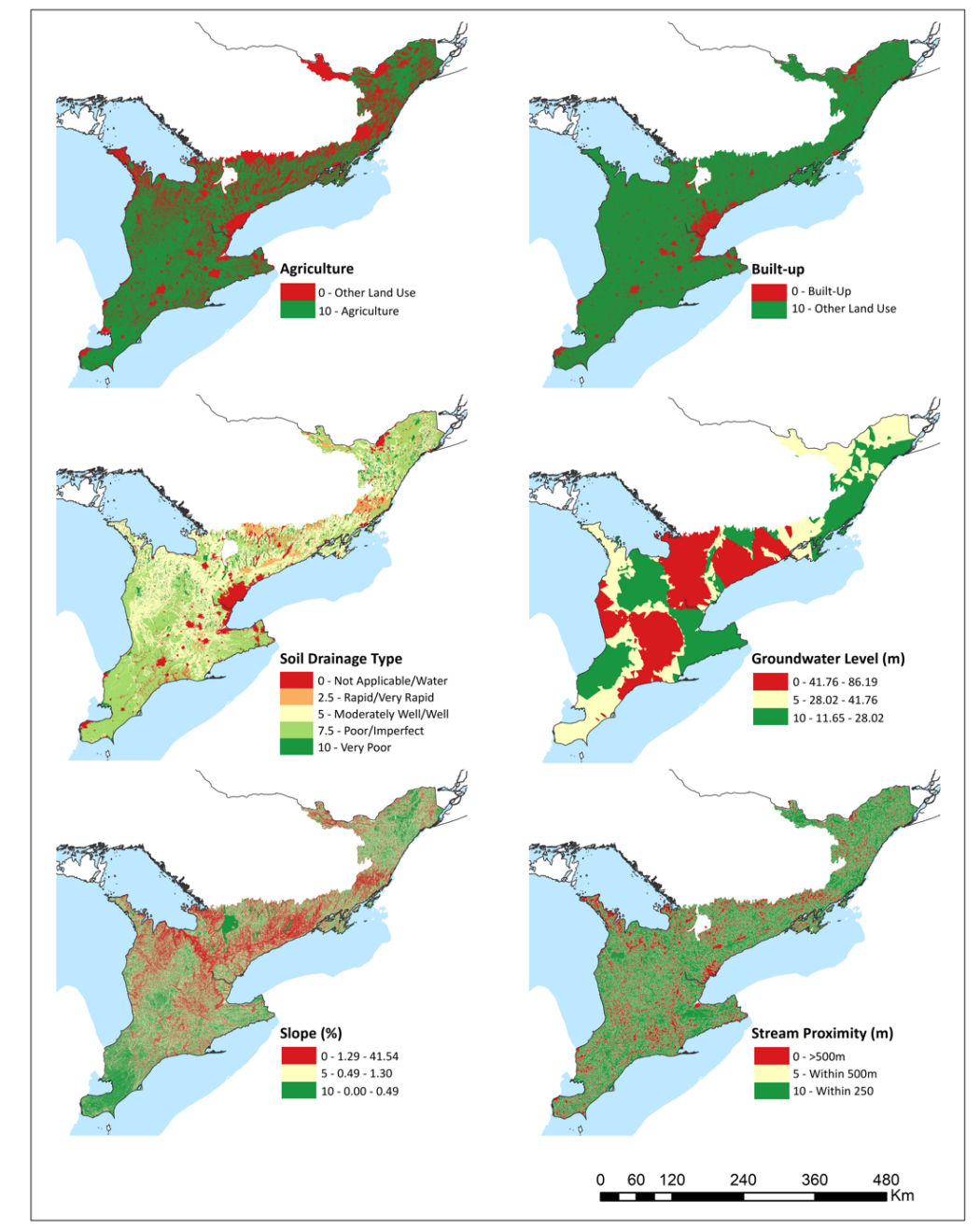

Figure 2. The six wetland reconstruction criteria, their corresponding indicator classes, and normalization ranking for the wetland suitability index (WSI). Note: Major waterbodies were not mapped as they were considered constraint features-locations where reconstructed wetlands could not be placed.

(i) Agriculture: Due to the wetland loss to agricultural land use in Ontario specifically [31,32], it was included as a variable in the model with a ranking of 10 for agriculture and 0 for all other land use. Agricultural land offers a blank slate free of infrastructure or other barriers for wetland 
restoration, increasing the likelihood that it will serve as a suitable site $[27,46]$. (ii) Built-up: Roads, impervious surfaces, and infrastructure, which made up the built-up variable, were ranked into two classes, representing built-up, with a score of 0 , or not, with a score of 10 . If the landscape is already built with impervious associated surfaces it has low probability of being reconstructed as wetlands. (iii) Soil drainage: Many studies cited soil drainage to be prioritized in suitability models, as wetlands often consist of poorly drained soils. Soil type was ranked by drainage type, from rapidly drained (worst) with a score of 2.5 to very poorly drained (best) with a score of 10 . In addition, frequently inundated soils were included among the "very poorly drained" soil class to prioritize flood mitigation to sites that need it most. (iv) Groundwater: Sivakumar and Ghosh [18] prioritized shallower groundwater in their overlay analysis wetland mitigation plan. For the purpose of this study, a groundwater surface was interpolated using the Provincial Groundwater Monitoring Network (PGMN), consisting of 367 points [57]. Kriging was used to interpolate a continuous raster surface from the 367 PGMN groundwater depth values using ESRI's [56] ArcGIS 10.7. In addition to the interpolated surface, kriging produces an output variance layer, which unlike other interpolation methods, provides the user with the confidence values to statistically validate the predicted pixel values (Appendix A Table A1). Kriging spatial interpolation models with a mean prediction error (MPE) greater than and less than 0 represent under- and overestimation of kriged values in comparison to the actual measured values [58,59]. Underestimation of variability in the kriged surfaces is identified when the standardized root-mean square prediction error (SRMSPE) is $>1$, while a SRMSPE $<1$ represents an overestimation of variability $[59,60]$. The resulting groundwater surface was then reclassified into three quantile classes, ranking shallow with a score of 10 and a deep water table with a score of 0. (v) Slope: Wetlands require flat or gently sloping topography in order for water to collect [33,44-46]. Slope ranged from $0-41.54$ degrees with a mean of only 1.12 degrees. Quantile classes were used to divide slope into three rank classes, with a score of $10 \mathrm{for}$ a low/flat degree of slope to a high/steep degree of slope with a score of 0. (vi) Stream proximity: Darwiche-Criado [45] and Huang et al. [24] used $500 \mathrm{~m}$ as the threshold for proximity to streams in their wetland site selection processes. As freshwater streams are abundant in the Mixedwood Plains Ecozone, and most pixels were within $500 \mathrm{~m}$ of a stream network, $250 \mathrm{~m}$ and $500 \mathrm{~m}$ stream buffers were applied to create two classes of closeness, scoring 10 and 5, respectively. (vii) Major waterbodies: The waterbodies variable required only two classes (acceptable and not acceptable). This variable acted as a constraint in the model (locations where reconstructed wetlands could not be placed), unlike the six other variables of varying suitability $[44,61]$. The waterbodies variable was assigned a value of "NoData" for major waterbodies, while the rest of the pixels were assigned a 0 . This ensures that permanent waterbodies are not included in the final WSI surface.

\subsection{Literature Analysis for Index Weighting}

There remains no agreed method for weighting indicators (e.g., wetland suitability criteria) or sub-indices when creating a multi-metric composite index (e.g., wetland suitability index; WSI). Therefore, a heuristic method for weighting the six non-constraint wetland suitability criteria was created through a scoping review of relevant literature. Scoping reviews of relevant literature lend way to informed decision-making based on collective knowledge [62]. This review will be used to determine the relative importance, and therefore the weighting, of each variable in the index. By considering the relative importance of each suitability variable through popularity in studies, many professional opinions were considered at once, effectively reducing bias and crowdsourcing consensus. To begin the scoping review, a query was designed to capture articles in ProQuest's Science and Technology database relevant to this study to ensure a wide search without duplicates [63]. The query ("Wetland reconstruction" OR "wetland restoration" OR "wetland suitability" OR "wetland creation" OR "wetland site suitability") AND ("multi-criteria" OR "index" OR "indicator" OR "GIS") was then further narrowed down by including only peer-reviewed articles, in English, from the past 10 years. The search included the entire contents of each item and was not limited geographically (as this resulted in too few items). Next, content analysis on the selected articles was carried out to find the 
number of relevant articles that considered each variable [64]. To ensure consistency between searches, search terms were determined using one word that best described the variable.

The relative importance of each wetland suitability criterion was decided by the number of articles where it appeared in the relevant literature. Using the Analytical Hierarchy Process (AHP), the relevant importance of each variable can be used to determine each variable's weight in the model and therefore its influence on the result $[61,65]$. Similar studies on creating raster surfaces for environmental planning scenarios have used Saaty's [65] AHP to find the importance of criteria in relation to each other, and to the project's goal (in this case wetland reconstruction) $[44,61,66]$. As the variable major waterbodies acted as a constraint in the model, it only represented the inclusion (rank $=0$ ) or exclusion (rank $=$ NoData) and therefore was not weighted with the other six variables of varied rankings. Every remaining relationship was then classified on Saaty's [65] nine-point reciprocal scale (Table 3). Based on the following differences in their relative counts, relationships between criteria were classified into equal groupings: 1 -equal (+/-0), 3-moderate (+/-75-150), 5-strong (+/-225-300), 7-very strong $(+/-375-450)$, or 9 -extreme $(+/->525)$ in their relative importance to the goal of wetland reconstruction (Table 3). Variables were then assigned the corresponding value $(1,3,5,7,9)$ if they were of more importance in the relationship, or the reciprocal value $(1,1 / 3,1 / 5,1 / 7,1 / 9)$ if they were of less importance. Intermediate values $(2,4,6 \ldots$ etc.) were assigned if differences in count fell between the above categories. The resulting pairwise comparison matrix represents each variable's relative importance to wetland suitability based on the literature content analysis (Table 3). Following the creation of the pairwise comparison matrix, each value must be normalized by the sum of its corresponding column, creating the normalized pairwise metrics (Appendix A Table A2). The criteria weights were then calculated by summing each row and dividing by the number of variables (see Table 3).

Table 3. Pairwise comparison matrix of seven chosen wetland suitability criteria (note: Waterbodies were constraint features). Method adopted from Saaty's [65] nine-point reciprocal scale.

\begin{tabular}{cccccccc}
\hline & Soil Drainage & Streams & Groundwater & Built-Up & Agriculture & Slope & Waterbodies \\
\hline Soil Drainage & 1 & 6 & 8 & 6 & 4 & 9 & N/A \\
Streams & $1 / 6$ & 1 & 4 & $1 / 2$ & $1 / 3$ & 5 & N/A \\
Groundwater & $1 / 8$ & $1 / 4$ & 1 & $1 / 4$ & $1 / 6$ & 3 & N/A \\
Built-up & $1 / 6$ & 2 & 4 & 1 & $1 / 3$ & 5 & N/A \\
Agriculture & $1 / 4$ & 3 & 6 & 3 & 1 & 7 & N/A \\
Slope & $1 / 9$ & $1 / 5$ & $1 / 3$ & $1 / 5$ & $1 / 7$ & 1 & N/A \\
Waterbodies & N/A & N/A & N/A & N/A & N/A & N/A & N/A \\
\hline
\end{tabular}

For the resulting weights to be considered acceptable, the consistency within the weights was checked using the following standards [65]: The consistency ratio (CR) describes the level of inconsistency in the model. A consistency ratio of $<0.1$ is considered the acceptable threshold. For this process, each value in the pairwise comparison matrix is multiplied by its criteria weight. When solved, the resulting consistency matrix can be used to calculate the weighted sum value (or sum of each row; Appendix A Table A3). The weighted sum value is divided by the corresponding criteria weight, and the result is summed and averaged, which $=\lambda \max$. To calculate the consistency index $(\mathrm{CI})$,

$$
\begin{gathered}
\text { If } \mathrm{n}=6 \text { and } \lambda \max =6.4783 \\
(\mathrm{CI})=(\lambda \max -\mathrm{n}) /(\mathrm{n}-1) \\
\text { Then } \mathrm{CI}=0.0967
\end{gathered}
$$

The consistency ratio (CR) is CI divided by the random index (RI)—determined by $n$ :

$$
\begin{gathered}
\mathrm{CR}=\mathrm{CI} / \mathrm{RI} \\
\mathrm{RI}=1.24 \text { when } \mathrm{n}=6 \\
\mathrm{CR}=0.0771
\end{gathered}
$$


Therefore, the CR is 0.0771 and the proportion of inconsistency is considered acceptable. The final ranking of each criterion represents its suitability to wetland landscapes while weighting represents each criterion's relative importance to wetland suitability based on prevalence in relevant literature.

\subsection{Wetland Suitablity Index Validation}

High suitability sites, also referenced as "best sites," from the WSI were determined by selecting those locations one standard deviation above the mean WSI score from the weighted composite raster. Comparison of WSI best sites with historic and existing wetland databases helps to understand WSI predictions of most suitable sites for wetland reconstruction. Utilizing the location of historic wetlands helps to focus efforts on wetland reconstruction by confirming the existence of suitable wetland criteria where present-day wetlands do not exist [67]. To account for the extensive wetland loss in Southern Ontario, best sites were compared with both the Ducks Unlimited Canada (DUC) historic wetland layer and the Land Information Ontario (LIO) existing wetlands layer. To remain consistent with the $50 \mathrm{~m}$ cell size of the rest of the study, wetlands under $1275 \mathrm{~m}^{2}$ (or half of the $2500 \mathrm{~m}^{2}$ cell size) were deleted from each vector file. This ensured that wetlands that were too small to be of at least half of one $50 \mathrm{~m}$ pixel were not transformed into much larger wetlands when rasterized. Next, binary rasters were created for both sets: (i) best sites and historic, and (ii) best sites and existing. Binary similarity coefficients can be used to show similarity in the distribution of features between two areas in ecological studies [68-70]. For the purpose of this study, the Jaccard index was used to measure the shared presence of wetlands in the WSI best sites raster with existing and historic wetlands. The Jaccard index [71] is one of the most widely used indices for quantifying similarity of binary data in ecology and biogeography; albeit, it does not consider negative matches [72]. In ESRI's [56] ArcMap 10.7, the raster calculator was used to find the intersection (\& operator) and union (| operator) between WSI best sites and both existing and historic wetlands. The Jaccard index was calculated by dividing the intersection by the union in each case. The Jaccard's index shows complete dissimilarity where Jaccard $=0$, and complete similarity where Jaccard $=1$.

\subsection{Wetland Suitablity "Hot Spot" Analysis}

The first law of geography asserts that near things in space are more similar (spatially autocorrelated) than farther apart things [73]. To help answer this study's guiding research questions, a two-step spatial analysis was conducted to test the global level of spatial autocorrelation and illustrate statistically significant spatial clusters of wetland suitability using Getis-Ord General G and Getis-Ord $\mathrm{Gi}^{*}$, respectively. Getis-Ord General G is considered a global test of spatial autocorrelation; Getis-Ord $\mathrm{Gi}^{*}$ is recognized as a local index of spatial association (LISA) test and is often used as a "hot spot" analysis [74]. Both global and local Getis-Ord tests compute $z$-scores and $p$-values, specifying whether features are non-randomly distributed (global) and where those feature's patterns are located (local) [75]. For statistically significant positive $z$-scores, the larger the $z$-score, the greater the clustering of high values (hot spot); for negative $z$-scores, the smaller the $z$-score, the greater the clustering of low values (cold spot; [56]).

Census subdivisions [76] and quaternary watershed boundaries [77] were chosen as aggregation boundaries for the spatial univariate tests, as they had a similar number of features for results comparison (261 and 296, respectively) without oversimplifying changes in wetland suitability over the study area. From an environmental management perspective, the use of both political and natural boundaries provides municipal and regional planning decision-makers context, which remained consistent with the goals of this study. The Zonal Statistics to Table tool was used to aggregate and calculate the mean WSI value for each polygon, which could then be attribute joined to its corresponding polygon. For both the global General $\mathrm{G}$ and local Gi ${ }^{*}$ tests, distance thresholds were set to $32.2 \mathrm{~km}$ and $33.0 \mathrm{~km}$ for census subdivisions and watersheds, respectively; the Calculate Distance Band, within the Neighbor Count tool, revealed the kernel search distance when eight neighbors were reached for all features. The local Gi* statistic allowed each feature's $z$-score to be illustrated, and was used to display 
geographic "hot spots" and "cold spots" of mean WSI across the study area census subdivisions and watersheds. The aforementioned spatial analysis procedures and Getis-Ord non-stationarity tests were conducted using ArcMap 10.7 Spatial Statistics tools [56].

\section{Results}

\subsection{Index-Ranking and Weighting}

The literature review drew 1253 results of relevant documents using the search query ("Wetland reconstruction" OR "wetland restoration" OR "wetland suitability" OR "wetland creation" OR "wetland site suitability") AND ("multi-criteria" OR "index" OR "indicator" OR "GIS"). These were limited to English, peer-reviewed full texts from the last 10 years. All searches were within the text (not limited to the title only) and duplicates were removed. The content analysis for each variable drew in the following counts: $($ agriculture $)=754,($ urban $)=653,($ soil $)=964,($ groundwater $)=447,($ slope $)=358$, and $\left(\right.$ stream $\left.^{*}\right)=608$. After undergoing the Analytical Hierarchy Process (AHP), the three criteria with the highest influence (weighting) on the index were soil drainage $(48.2 \%)$, agriculture $(21.8 \%)$, and built-up (12.3\%). The remaining three criteria accounted for the outstanding $18 \%$ of the model (Table 4$)$.

Table 4. Range, classes, ranking, and weighting for the seven criteria used in the wetland suitability index (WSI).

\begin{tabular}{|c|c|c|c|c|c|}
\hline Criterion & Symbol & Range & Classes & Rank & Weight \\
\hline Agriculture & $\mathrm{Ag}$ & Agriculture-Not & Not & 0 & 0.218 \\
\hline \multirow{2}{*}{ Built-up Area } & $\mathrm{Bu}$ & (Best) Not-Built-up & Built-up & 0 & 0.123 \\
\hline & \multirow{4}{*}{ Sd } & & Very Poorly Drained & 10 & \multirow{4}{*}{0.482} \\
\hline \multirow{3}{*}{ Soil Drainage Type } & & (Best) Very Poorly & Poorly and Imperfectly Drained & 7.5 & \\
\hline & & Applicable/Water & Rapidly/Very Rapidly Drained & 2.5 & \\
\hline & & & Not Applicable/Water & 0 & \\
\hline \multirow{4}{*}{$\begin{array}{l}\text { Groundwater } \\
\text { Level (m) }\end{array}$} & \multirow{4}{*}{ Gw } & \multirow{4}{*}{ (Best) 11.65-86.19 } & $11.65-28.02$ & 10 & \multirow{4}{*}{0.047} \\
\hline & & & $28.02-41.76$ & 5 & \\
\hline & & & $41.76-86.19$ & 0 & \\
\hline & & & $0-0.4868$ & 10 & \\
\hline Stream Proximity & $\mathrm{Sp}$ & 250-Within 500 & Within $500 \mathrm{~m}$ & 5 & 0.102 \\
\hline \multirow{2}{*}{ Major Waterbodies } & \multirow{2}{*}{ Mw } & (Best) Not-Major & Major Waterbody & NoData & \multirow{2}{*}{ Constraint } \\
\hline & & Waterbody & Not & 0 & \\
\hline
\end{tabular}

The wetland suitability index (WSI) was created based on the aforementioned justified seven criteria, normalized from 0 (low suitability) to 10 (high suitability), and illustrated through a weighted composite raster. Therefore, using the symbols from Table 4 , the WSI equation is as follows:

$$
\begin{gathered}
\text { WSI }= \\
\left(\mathrm{Ag}^{*} 0.218\right)+\left(\mathrm{Bu}^{*} 0.123\right)+\left(\mathrm{Sd}^{*} 0.482\right)+\left(\mathrm{Gw}^{*} 0.047\right)+\left(\mathrm{Sl}^{*} 0.028\right)+\left(\mathrm{Sp}^{*} 0.102\right)+(\mathrm{Mw})
\end{gathered}
$$

\subsection{Wetland Restoration Suitablity}

The WSI was created using seven variables from a variety of sources that represent geographical needs for wetland reconstruction, reflect natural wetland form, and make best use of ecosystem services (Figure 3). These data were combined to create this index for which suitable sites for wetland construction could be determined. After summing the aforementioned criteria, the resulting WSI raster surface had a suitability range of (worst) $0.000-9.999$ (best) with a mean suitability of 6.40 and a standard deviation of 1.96. Raster cells with WSI index values one standard deviation above the mean (>8.35) were chosen as "best sites." These made up $14.529 \%$ of pixels in the final wetland 
suitability surface. If each cell is 0.25 ha at a $50 \mathrm{~m}$ resolution, then best sites have a combined area of $993,299.25$ ha. The resulting surface accentuated high wetland suitability in the southernmost region of Ontario, the Niagara Peninsula, and the northeast part of the study area south of Ottawa. Areas of very low suitability can largely be attributed to the presence of urban areas, and not applicable/rapidly drained soils.

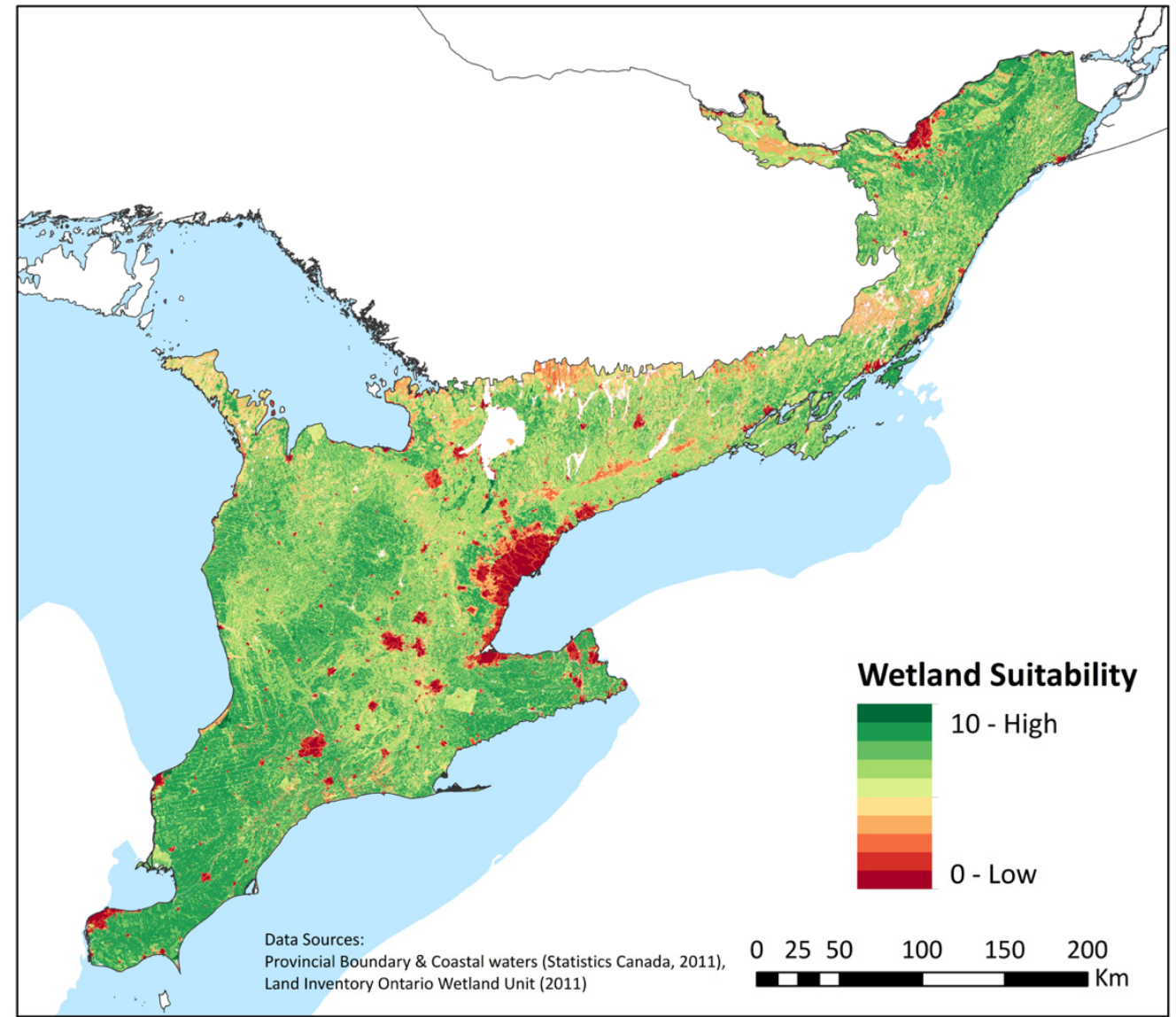

Figure 3. Map illustrating the wetland suitability index (WSI) across Ontario, Canada's Mixedwood Plains Ecozone.

\subsection{Validation with Historic and Existing Wetlands}

Most suitable sites (best sites) established from the WSI were compared and contrasted with historic and existing wetlands (Figure 4). The isthmus found between Lake St. Clair and Lake Erie in the southernmost region of the study area has undergone significant wetland loss since presettlement; a majority of suitable sites indicated by WSI intersected with Ducks Unlimited Canada's historic wetlands here (Figure 4A). The northeast region of the study area, especially lands south of Ottawa, also had a high degree of overlap between WSI best sites and the historic wetlands data set. That said, greater corroboration between WSI and once-present wetlands was found throughout the Mixedwood Plains Ecozone. When contrasting WSI with existing wetlands, the intersect analysis rendered sparse but consistent results throughout the study area (Figure 4B). A greater number of WSI best sites intersected with existing wetlands in the central portion of the study area. When contrasting WSI best sites with historic and existing wetland data sets, the Jaccard coefficient was used to evaluate spatial data overlap. The Jaccard coefficient scores between 1 and 0 , with 1 being completely similar or overlapped and 0 having no similarity or overlap. Validation results between WSI best sites and historic wetlands resulted in Jaccard $=0.231$, indicating some similarity. Validation results between WSI best sites and present existing wetlands resulted in Jaccard $=0.028$, indicating greater dissimilarity. 
While the similarity between existing wetlands and best sites is lower, it is important to note that many of these landscapes have undergone land-cover change and their presettlement wetlands have been repurposed into other land uses. In sum, less than $30 \%$ of presettlement wetlands remain present-day for existing overlap validation, which is particularly evident within the isthmus of the southernmost region of the study area.
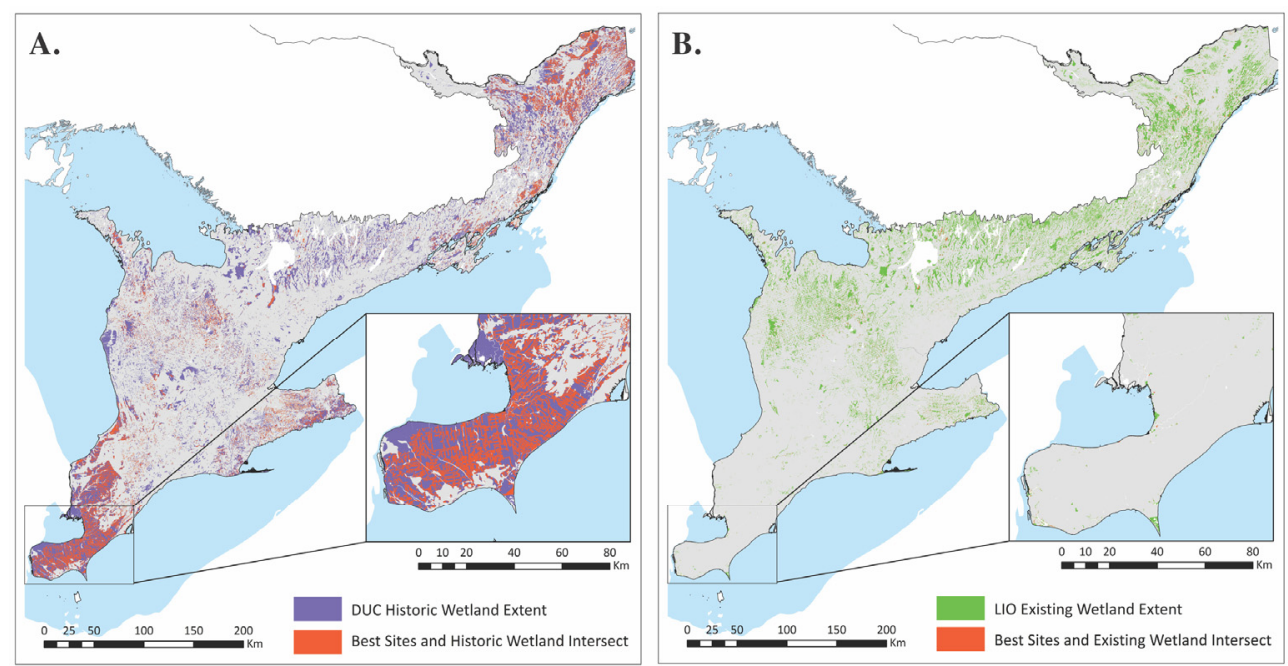

Figure 4. Overlay analysis displaying: (A) the intersection of the Ducks Unlimited Canada (DUC) historic wetland extent and best sites designated by the wetland suitability index (WSI) and (B) the intersection of a Land Information Ontario (LIO) existing wetlands and best sites designated by the WSI.

\subsection{Hot Spot Analysis}

The global Getis-Ord General G analysis revealed that the patterns of mean WSI, aggregated to both the census subdivisions $(n=261)$ and quaternary watersheds $(n=296)$, were not significantly different than a random spatial distribution. Regarding the governmental subdivisions, the observed Getis-Ord General G score was 0.031 and the $z$-score was 1.137 . Concerning the watersheds, the observed Getis-Ord General G score was 0.029 and the $z$-score was 0.133 . That said, the local Getis Ord Gi* statistic identified spatial clusters of low and high wetland suitability for both the census subdivision and quaternary watershed boundaries (Figure 5).

Of the 261 census subdivision features, 60 were of significant spatial clustering with less than $1 \%$ chance of being random, and 35 were spatially clustered to some degree of confidence (Figure 5A). Four of five $99 \%$ confidence hot spots were present in the southernmost region's Middlesex and Lambton census divisions, signifying high wetland suitability in those political management boundaries on the west side of the study area. Hot spots reporting lower degrees of confidence were found surrounding the municipalities of Ottawa, Stratford, and Waterloo, signifying marginal wetland suitability around those cities. Cold spots made up 25 of the significant census subdivisions. All four clustered subdivision cold spots of high $(99 \%)$ confidence were within the Toronto census metropolitan area (CMA), surrounded by five clustered subdivisions at 95 and $90 \%$ confidence level. Multiple negative clustered subdivisions were also found surrounding the City of Cambridge and within the Peterborough census division.

Of 296 watershed boundaries, 125 were spatially clustered to a degree of confidence, including 18 watersheds at $99 \%$ confidence, 30 at 95\% confidence, and 16 at $90 \%$ (Figure 5B). Notably, four of the 18 hot spot watersheds at the 99\% confidence level encompassed the Ausable River watershed, signifying high wetland suitability in those environmental management boundaries on the west side of the study area. Other high-confidence hot spots surrounded the Sydenham River, the Thames River outlet, and the Teeswater River outlet. Cold spots accounted for 61 of the 125 significantly clustered watersheds. Of the 33 negatively clustered watersheds, 13 were grouped at $99 \%$ confidence along the northwest shore of Lake Ontario around Toronto, including the Credit River, Don River, and Humber 
River watersheds. Other negative or "cold spot" clustered watersheds (with less than $1 \%$ chance of being random) were found in the Georgian Bay peninsula in the northwest of the study area. Notable cold spot watersheds, at the $95 \%$ confidence level, were also found in the Kawartha Lakes, Gull River, and Crowe Lake watersheds in the north-central part of the study area.
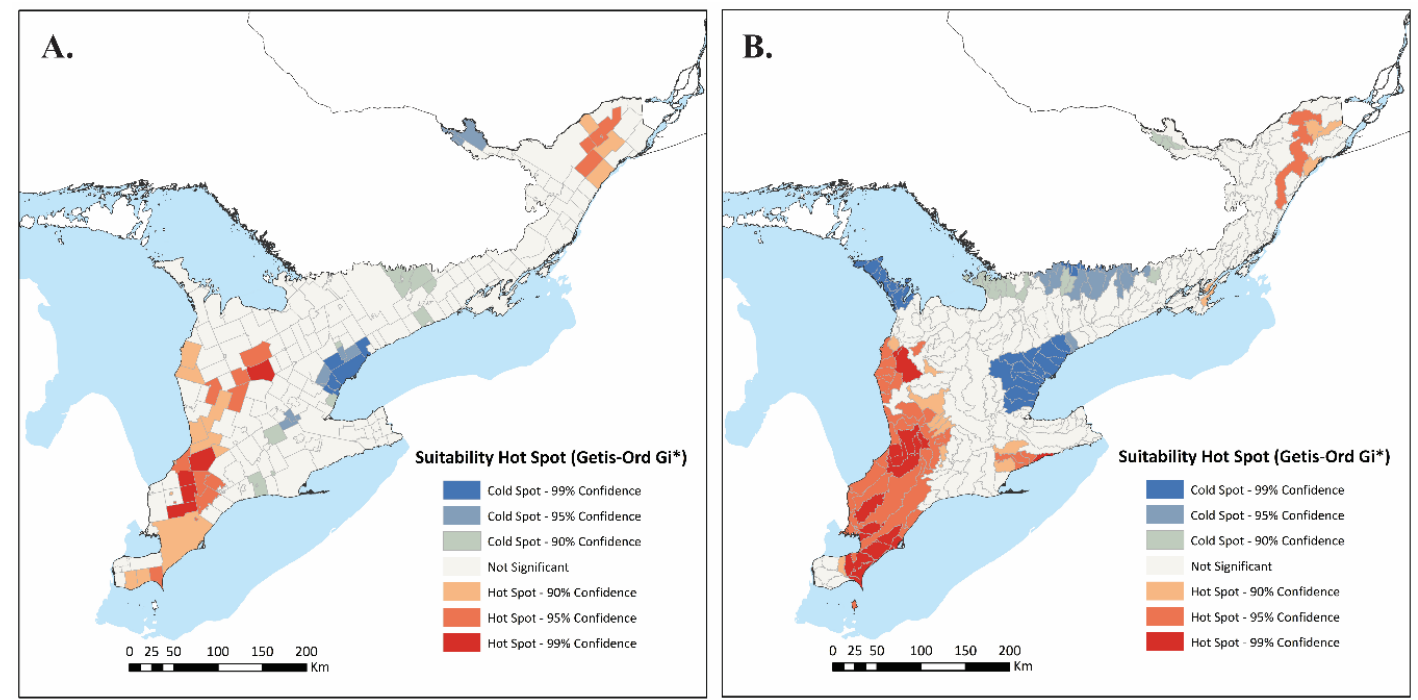

Figure 5. Hot spot analysis using Getis-Ord Gi* statistic for (A) census subdivisions and (B) quaternary watershed boundaries using mean wetland suitability index (WSI) values per areal unit. The threshold distance parameter was determined within this study and set to $32.2 \mathrm{~km}$ and $33 \mathrm{~km}$ for census subdivisions and watersheds, respectively.

\section{Discussion}

\subsection{Wetland Suitablity Criteria and Their Importance}

The first research question asked: Which physical and ecological landscape criteria represent high suitability for wetland reconstruction? Cited articles for similar studies often named shallow groundwater, proximity to streams, soil drainage, and low slope as ideal properties for wetland reconstruction. Criteria were also considered based on previous wetland studies in the Mixedwood Plains. The Detailed Soil Survey (DSS) from the Canada Land Inventory (CLI) contained updated data from previous CLI soil surveys. These data are an updated version of that used by Snell [31] to create the first wetland inventory in Ontario. Additionally, Duck's Unlimited Canada [32] utilized the CLI soil survey (combined with quaternary geology) to identify poorly and very poorly drained soils as indicators of historic wetlands. By using a current soil survey and ranking poorly and very poorly drained soils highest, consistency was maintained with these previously conducted studies. Last, to incorporate ecosystem services, two factors were considered areas of need: agriculture, and frequently inundated soils. In Ontario, where many wetlands have been eliminated due to intensive agriculture, the landscape is not only suitable for reintroduction of wetlands, but needs them [27]. Agriculture characterized by flood risk, runoff, soil erosion, and low biodiversity was included in the criteria in contrast to a wetland's ability to mitigate floods, introduce and maintain biodiversity, slow erosion, and store and filter water [78,79]. Frequently inundated soils were included among the highest-ranking soil class to prioritize flood mitigation to sites that need it most. The ranking of each criterion represents its suitability to a wetland project with a range from 0 (worst) to 10 (best).

Existing wetlands were left out of the wetland suitability index (WSI) criteria for several reasons. Few WSI best sites intersected with existing wetlands, as revealed by the Jaccard index; greater similarity was found between best sites and historic wetlands, corroborating the severity of historic wetland cannibalization. The mass eradication of approximately $72 \%$ of Ontario's wetlands to dredging, filling, 
and alterations to hydrology meant that existing wetlands could not be considered representative of Ontario's suitable land for wetland sites. Similarly, the remaining existing wetlands are not necessarily emblematic of the most ideal quality in Ontario, but more likely land that was left in its original condition, as it was not desirable for another land use. In sum, if the WSI were to incorporate the minimally existing wetlands into its criteria then it would be biased away from landscapes more suitable for reconstruction. These important findings were evident from the Jaccard spatial overlay analysis found within this study. Therefore, due to the extreme eradication of wetlands globally and their sparse spatial patterning across study areas, caution should be used when incorporating existing wetland inventories into future suitability analyses.

The second research question asked: Of common wetland suitability metrics, which are most important? In this paper, a novel technique for advancing wetland suitability and prioritization was created by analyzing relevant connected literature via scoping review. This served as an objective approach for understanding each criterion's relative importance to wetland suitability by considering the collective contents of many research articles at once. Using Saaty's [65] Analytical Hierarchy Process (AHP) for determining multi-criteria weights, the relative importance of each variable from the literature review was transformed into criteria weights for the WSI. The criteria "soil drainage" and "agriculture" drew the most results, with weightings of $48.2 \%$ and $21.8 \%$, respectively. The criteria search term "slope" had the fewest results and was the least important criterion, weighted at only $2.8 \%$. In retrospect, it was considered that this literature review method for creating sub-index weights may be capturing research popularity rather than accepted scientific need. A fertile area for future research exists with using literature reviews most effectively for index weighting. It is hoped through the example of this research that other environmental management index initiatives will consider adopting this mixed-method technique to suit their needs (i.e., restoration of the Prairie Pothole Region).

\subsection{Wetland Suitability Patterns and Characteristics}

The third research question asked: Can a multi-criteria WSI effectively locate high and low wetland suitability across the Ontario Mixedwood Plains Ecozone? Getis-Ord Gi* charted statistically significant "hot spots" and "cold spots" of wetland suitability. Best sites were clustered around the City of Ottawa, within the isthmus found between Lake St. Clair and Lake Erie, and on the Niagara Peninsula. These regions are characterized homogenously with low slope, high amounts of agriculture land, and poor/very poor soil drainage. Medium suitability was scattered throughout central and northern Ontario and reflects the spatial patterns of agriculture, shallow groundwater depth, higher slopes, and well-drained soils. Roads and urban areas had the lowest values. Getis Ord $\mathrm{Gi}^{*}$ analysis indentified statistically signifcant local clusters of high and low suitabilty. High confidence (99\%) cold spots occur in Toronto due to its dense urban landscape. Statistically significant hot spots made up $13.4 \%$ of census subdivisions and $21.62 \%$ of quaternary watersheds. Hot spots of varying (90-99\%) confidence were present for both census subdivision and quaternary watershed bondaries surrounding the City of Ottawa and in the southernmost portion of the Mixedwood Plains Ecozone moving north. These are largely agricultural areas with phyiscal characteristics that could support wetlands such as poorly drained soils and shallow groundwater.

Last, the fourth research question asked: How do best sites from the WSI compare and contrast to both inventories of presettlement wetlands and current existing wetlands? Ducks Unlimited Canada presettlement wetlands and Land Information Ontario existing wetlands were used in an overlay analysis for validating WSI best sites. Due to the high ranking and weighting (10 at 21.8\%) of agriculture lands in the index, best sites were largely located on agricultural landscapes compared to any other land cover. This resulted in the index identifying few existing wetlands as they fell into the "Not" agriculture class ranked at 0 . This, in contrast with the much higher similarity between WSI best sites and historic wetlands, testifies to the mass erasure of wetlands in Ontario specifically due to agriculture. This research has demonstrated that many of the areas in which wetlands have been removed from the landscape may still be suitable for sustaining a wetland habitat. Areas with suitable sites and 
few existing wetlands should be prioritized in wetland restoration and reconstruction planning. Suitable sites bordering existing wetlands could represent opportunities to increase patch sizes and bolster connectivity between existing habitats. Areas where best sites intersect with presettlement wetlands can be viewed as opportunities to restore historic wetlands, as these sites still consider present-day obstacles such as infrastructure and were formerly successful wetlands.

\subsection{Recommendations and Future Considerations}

Canada's Federal Policy on Wetland Conservation of 1991 recognizes the socioeconomic value of wetlands in the form of tourism, sustaining water resources, hunting, fishing, and forestry [80]. The federal policy aims to protect these functions by managing national parks, promoting research, and encouraging the conservation of wetlands in decision-making processes [81]. In 2014, the National Wetland Conservation Fund (NWCF) was created as part of the Government of Canada's National Conservation Plan (NCP); however, the $\$ 50$ million (CAD) allocation was redistributed to other causes in 2019 when the plan was cut short [82]. That said, the United States Fish and Wildlife Service, through the North American Wetlands Conservation Act (P.L. 101-233) of 1989 [83], continues to generate funding for the protection of wetland habitats for migratory birds in the United States, Mexico, and Canada. At the provincial level in Ontario, a convoluted system remains for administering and implementing policies and legislation governing wetlands. Since the establishment of the first provincial wetland policy in 1984, the management of these keystone landscape features is now done through a variety of policies that include over 20 unique legislation items governed and executed by five provincial ministries, two federal departments, a provincial agency (Niagara Escarpment Commission), 36 conservation authorities, and 444 municipalities [19]. Despite a strong promise by governmental and non-governmental organizations, it remains financially and logistically impossible to restore all wetlands to their presettlement landscape conditions. Therefore, effective wetland restoration, management, and planning requires uncomplicated near-, mid-, and long-term policies that simplify management processes and prioritize limited financial resources.

Despite the noteworthy research contributions from this study, there are limitations that inform future research directions. The limitations largely involve methodological issues with data from various sources and of various quality. While the Mixedwood Plains Ecozone includes Manitoulin Island and surrounding smaller islands, these had to be removed from the study due to a lack of data. However, the island was not included in other studies such as Ducks Unlimited Canada's Southern Ontario Wetland Analysis and thus had no loss of continuity in comparing the final suitability surface with preceding studies. Additionally, some data sources were over a decade old, of varying resolutions, or were compilations of old and new data sets. These temporal and resolution incongruities may have compromised the results, but best practices were always practiced. These data include the Agricultural Resource Inventory (ARI), as well as the Detailed Soil Survey (DSS) from the Canada Land Inventory (CLI). To account for lower resolution datasets, finer resolution data had to be simplified to the determined resolution of $50 \mathrm{~m}$. This resulted in some data loss, yet increased confidence in WSI outcomes. Last, the creation of a groundwater raster surface involved kriging interpolation, which can provide only a best estimate of groundwater depth. With the growing quantity of higher resolution geospatial data, future research can be improved by including more criteria or using more current data at a finer scale. For instance, these could include landscape ecology metrics that capture additional ecosystem goods and services such as habitat physical connectedness, biodiversity, and recreation $[84,85]$. Progressing this research to the next level using the aforementioned ideas will help to meet the Ontario Ministry of Natural Resources and Forestry goals, which call for a reinstatement of wetland area and function to landscapes where loss has been the greatest.

\section{Conclusions}

Wetlands provide diverse habitats and ecosystem goods and services, which are increasingly valuable under the current conditions of global change. The overwhelming loss of wetland area in 
Southern Ontario calls for macroscale conservation planning initiatives. In response, this paper was created to deliver landscape planners, ecological restoration scientists, regional planners, and environmental managers and decision-makers an applied example for systematically evaluating wetland suitability across space in temperate climate zones. The use of geographic information systems (GIS) for decision-making has allowed for the creation of replicable processes, which can be altered to suit the needs of this project and its stakeholders. In addition, considering multiple wetland suitability criteria allowed for cost-effective, environmentally conscious planning. Through the incorporation of ecosystem services into these criteria, sites that represent the best possible reconstruction and restoration outcomes were identified. In other regions around the world, wetland indices have been implemented to identify suitable wetland reconstruction sites, however, such an index did not previously exist for Ontario. Therefore, this study provides the first macroscale study of wetland suitability across the Ontario Mixedwood Plains Ecozone by investigating and answering its four research questions.

Restoring and maintaining wetlands are critical for building resilience to global change, and knowledge, information, and new methods are required to prioritize environmental management efforts. Therefore, to aid major Canadian agencies in their macroscale wetland restoration efforts in Southern Ontario, this study had the applied goal of determining where the most suitable wetland restoration sites were spatially distributed in the Mixedwood Plains and how these best sites compare to historic and present models of wetlands in the area. The generation of the Wetland Suitability Index (WSI) was based on seven criteria, normalized from 0 (low suitability) to 10 (high suitability), and illustrated through a weighted composite raster. Similarities between historic wetland extent and the best sites generated by the WSI illustrated Ontario's potential to recover from historic wetland loss. Specifically, the overlay analysis revealed greater similarity between high suitability sites and presettlement wetlands, supporting the magnitude and severity of wetland cannibalization. The WSI framework provides a useful tool for understanding the spatial distribution of wetland suitability on a large scale for wetland restoration in Ontario's Mixedwood Plains. More specifically, a novel mixed-methods modeling approach to regional wetland restoration provides a prioritization tool for enhancing macroscale ecological connectivity, services, and resilience. Further, returning wetlands to the Mixedwood Plains Ecozone landscape of Canada would help to combat the negative impacts of global change on biogeochemical systems by reintroducing natural water filtration, stabilizing temperatures, increasing biodiversity, improving ecological services, decreasing runoff, and reducing flood risk. This research has provided a roadmap for informing policies and planning that meet this goal. In sum, studies like this one help to mend humanity's bond with its life-supporting biogeochemical systems.

Author Contributions: Conceptualization, S.J.M. and R.R.S.; methodology, S.J.M. and R.R.S.; data curation, S.J.M.; formal analysis, S.J.M. and R.R.S.; investigation, S.J.M., R.R.S., and K.W.F.; project administration, R.R.S.; visualization, S.J.M. and R.R.S.; writing-original draft, S.J.M., R.R.S., K.W.F, B.R.M., and G.R.; writing-review and editing, R.R.S., K.W.F., B.R.M, and G.R.; funding acquisition, R.R.S. All authors have read and agreed to the published version of the manuscript.

Funding: This study was funded by Ryerson University. The University had no role in the design of the study; in the collection, analyses, or interpretation of data; in the writing of the manuscript, or in the decision to publish the results.

Acknowledgments: Mallory Carpenter from Ducks Unlimited Canada provided valuable insight and data necessary for completing this study. R.R.S. would like to thank L.L. Shaker and D.E. Shaker from GeoEco Design and K.M. Schertzing, A.M. Miller, and W.A. Miller from Meristem Financial Services Inc. for sharing their time, which was necessary for completing this research and paper.

Conflicts of Interest: The authors declare no conflict of interest. 


\section{Appendix A}

Table A1. Kriging model error statistics for the Provincial Groundwater Monitoring Network (PGMN) interpolated across the 367 well-depth sample locations for the Mixedwood Plains Ecozone.

\begin{tabular}{ccc}
\hline Abbreviation & Description & Statistic Value \\
\hline MPE & Mean prediction error & -0.7296 \\
RMSPE & Root-mean-square prediction error & 29.3025 \\
MS & Mean standardized & -0.0234 \\
ASE & Average standard error & 31.2808 \\
SRMSPE & Standardized root-mean-squared prediction error & 0.9384 \\
\hline
\end{tabular}

Notes: Ordinary kriging conducted using ESRI's (2019) ArcGIS 10.7 software; 12 neighbors.

Table A2. Normalized pairwise metrics for the six non-constraint wetland variables for weighting in the Wetland Suitability Index (WSI). Method adapted from Saaty's (1977) Analytical Hierarchy Process (AHP).

\begin{tabular}{ccccccc}
\hline & Soil Drainage & Streams & Groundwater & Built-Up & Agriculture & Slope \\
\hline Soil Drainage & 0.5496 & 0.4819 & 0.3429 & 0.5479 & 0.6693 & 0.3000 \\
Streams & 0.0916 & 0.0803 & 0.1714 & 0.0457 & 0.0558 & 0.1667 \\
Groundwater & 0.0687 & 0.0201 & 0.0429 & 0.0228 & 0.0279 & 0.1000 \\
Built-up & 0.0916 & 0.1606 & 0.1714 & 0.0913 & 0.0558 & 0.1667 \\
Agriculture & 0.1374 & 0.2410 & 0.2571 & 0.2740 & 0.1673 & 0.2333 \\
Slope & 0.0611 & 0.0161 & 0.0143 & 0.0183 & 0.0239 & 0.0333 \\
\hline
\end{tabular}

Table A3. Consistency matrix for the six non-constraint variables for weighting in the Wetland Suitability Index (WSI). Used in calculating the consistency index (CI) and consistency ratio (CR) for the final wetland criteria weights. Method adapted from Saaty's (1977) Analytical Hierarchy Process (AHP).

\begin{tabular}{ccccccc}
\hline & Soil Drainage & Streams & Groundwater & Built-Up & Agriculture & Slope \\
\hline Soil Drainage & 0.4819 & 0.6115 & 0.3765 & 0.7374 & 0.8734 & 0.2504 \\
Streams & 0.0803 & 0.1019 & 0.1882 & 0.0615 & 0.0728 & 0.1391 \\
Groundwater & 0.0602 & 0.0255 & 0.0471 & 0.0307 & 0.0364 & 0.0835 \\
Built-up & 0.0803 & 0.2038 & 0.1882 & 0.1229 & 0.0728 & 0.1391 \\
Agriculture & 0.1205 & 0.3057 & 0.2824 & 0.3687 & 0.2184 & 0.1947 \\
Slope & 0.0535 & 0.0204 & 0.0157 & 0.0246 & 0.0312 & 0.0278 \\
\hline
\end{tabular}

\section{References}

1. Steffen, W.; Richardson, K.; Rockström, J.; Cornell, S.E.; Fetzer, I.; Bennett, E.M.; Biggs, R.; Carpenter, S.R.; de Vries, W.; de Wit, C.A.; et al. Planetary boundaries: Guiding human development on a changing planet. Science 2015, 347, 1259855. [CrossRef] [PubMed]

2. Rockström, J.; Steffen, W.; Noone, K.; Persson, Å.; Chapin, F.S.; Lambin, E.F.; Lenton, T.M.; Scheffer, M.; Folke, C.; Schellnhuber, H.J.; et al. A safe operating space for humanity. Nature 2009, 461, 472-475. [CrossRef] [PubMed]

3. Venter, O.; Sanderson, E.W.; Magrach, A.; Allan, J.R.; Beher, J.; Jones, K.R.; Possingham, H.P.; Laurance, W.F.; Wood, P.; Fekete, B.M.; et al. Sixteen years of change in the global terrestrial human footprint and implications for biodiversity conservation. Nat. Commun. 2016, 7, 12558. [CrossRef] [PubMed]

4. Liu, J.; Dietz, T.; Carpenter, S.R.; Alberti, M.; Folke, C.; Moran, E.; Pell, A.N.; Deadman, P.; Kratz, T.; Lubchenco, J.; et al. Complexity of Coupled Human and Natural Systems. Science 2007, 317, 1513-1516. [CrossRef] [PubMed]

5. Foley, J.A.; DeFries, R.; Asner, G.P.; Barford, C.; Bonan, G.; Carpenter, S.R.; Chapin, F.S.; Coe, M.T.; Daily, G.C.; Gibbs, H.K.; et al. Global Consequences of Land Use. Science 2005, 309, 570-574. [CrossRef]

6. Alberti, M. Advances in Urban Ecology: Integrating Humans and Ecological Processes in Urban Ecosystems; Springer: New York, NY, USA, 2008; ISBN 978-0-387-75509-0. 
7. Seneviratne, S.I.; Donat, M.G.; Mueller, B.; Alexander, L.V. No pause in the increase of hot temperature extremes. Nat. Clim. Chang. 2014, 4, 161-163. [CrossRef]

8. Bellard, C.; Leclerc, C.; Leroy, B.; Bakkenes, M.; Veloz, S.; Thuiller, W.; Courchamp, F. Vulnerability of biodiversity hotspots to global change. Glob. Ecol. Biogeogr. 2014, 23, 1376-1386. [CrossRef]

9. Yalcin, S.; Leroux, S.J. An empirical test of the relative and combined effects of land-cover and climate change on local colonization and extinction. Glob. Chang. Biol. 2018, 24, 3849-3861. [CrossRef]

10. Butchart, S.H.M.; Walpole, M.; Collen, B.; van Strien, A.; Scharlemann, J.P.W.; Almond, R.E.A.; Baillie, J.E.M.; Bomhard, B.; Brown, C.; Bruno, J.; et al. Global Biodiversity: Indicators of Recent Declines. Science 2010, 328, 1164-1168. [CrossRef]

11. Shaker, R.R. The spatial distribution of development in Europe and its underlying sustainability correlations. Appl. Geogr. 2015, 63, 304-314. [CrossRef]

12. Shaker, R.R.; Yakubov, A.D.; Nick, S.M.; Vennie-Vollrath, E.; Ehlinger, T.J.; Forsythe, K.W. Predicting aquatic invasion in Adirondack lakes: A spatial analysis of lake and landscape characteristics. Ecosphere 2017, 8, e01723. [CrossRef]

13. Shaker, R.R. A mega-index for the Americas and its underlying sustainable development correlations. Ecol. Indic. 2018, 89, 466-479. [CrossRef]

14. Shaker, R.; Ehlinger, T. Agricultural Land Fragmentation and Biological Integrity: The Impacts of a Rapidly Changing Landscape on Streams in Southeastern Wisconsin; University of Wisconsin-Milwaukee Fish Ecology Laboratory: Milwaukee, WI, USA, 2007; p. 50.

15. Shaker, R.R.; Ehlinger, T.J. Exploring Non-Linear Relationships between Landscape and Aquatic Ecological Condition in Southern Wisconsin: A GWR and ANN Approach. IJAGR 2014, 5, 1-20. [CrossRef]

16. Karr, J.R.; Chu, E.W. Restoring Life in Running Waters: Better Biological Monitoring; Island Press: Washington, DC, USA, 1998; ISBN 978-1-59726-277-4.

17. O'Reilly, N.; Ehlinger, T.; Shaker, R. The Development and Evaluation of Methods for Quantifying Risk to Fish in Warm-Water Streams of Wisconsin Using Self-Organized Maps: Influences of Watershed and Habitat Stressors; Northeastern University Center for Urban and Environmental Studies: Boston, MA, USA, 2007; p. 121.

18. Sivakumar, R.; Ghosh, S. Wetland spatial dynamics and mitigation study: An integrated remote sensing and GIS approach. Natur. Hazards 2016, 80, 975-995. [CrossRef]

19. OMNRF. A Wetland Conservation Strategy for Ontario 2017-2030; Queen's Printer for Ontario: Toronto, ON, Canada, 2017; p. 52.

20. National Research Council. Wetlands: Characteristics and Boundaries; National Academies Press: Washington, DC, USA, 1995; ISBN 978-0-309-58722-8.

21. Findlay, C.S.; Houlahan, J. Anthropogenic Correlates of Species Richness in Southeastern Ontario Wetlands. Conserv. Biol. 1997, 11, 1000-1009. [CrossRef]

22. Zorrilla-Miras, P.; Palomo, I.; Gómez-Baggethun, E.; Martín-López, B.; Lomas, P.L.; Montes, C. Effects of land-use change on wetland ecosystem services: A case study in the Doñana marshes (SW Spain). Landsc. Urban Plan. 2014, 122, 160-174. [CrossRef]

23. Zedler, J.B.; Kercher, S. Wetland Resources: Status, Trends, Ecosystem Services, and Restorability. Annu. Rev. Environ. Resour. 2005, 30, 39-74. [CrossRef]

24. Huang, N.; Wang, Z.; Liu, D.; Niu, Z. Selecting Sites for Converting Farmlands to Wetlands in the Sanjiang Plain, Northeast China, Based on Remote Sensing and GIS. Environ. Manag. 2010, 46, 790-800. [CrossRef]

25. Odgaard, M.V.; Turner, K.G.; Bøcher, P.K.; Svenning, J.-C.; Dalgaard, T. A multi-criteria, ecosystem-service value method used to assess catchment suitability for potential wetland reconstruction in Denmark. Ecol. Indic. 2017, 77, 151-165. [CrossRef]

26. Klemas, V. Using Remote Sensing to Select and Monitor Wetland Restoration Sites: An Overview. J. Coast. Res. 2013, 29, 958-970. [CrossRef]

27. Hobbs, R.J. Old Fields: Dynamics and Restoration of Abandoned Farmland; Island Press: Washington, DC, USA, 2012; ISBN 978-1-61091-098-9.

28. Giblett, R.J. Canadian Wetlands: Places and People; Intellect Ltd.: Bristol, UK, 2014; ISBN 978-1-78320-176-1.

29. Canada Committee on Ecological (Biophysical) Land Classification; National Wetlands Working Group; Warner, B.G.; Rubec, C.D.A. The Canadian Wetland Classification System, 2nd ed.; Wetlands Research Branch, University of Waterloo: Waterloo, ON, Canada, 1997; ISBN 978-0-662-25857-5. 
30. Classens, M. The transformation of the Holland Marsh and the dynamics of wetland loss: A historical political ecological approach. J. Environ. Stud. Sci. 2017, 7, 507-518. [CrossRef]

31. Snell, E.A. Wetland Distribution and Conversion in Southern Ontario; Working paper; Inland Waters and Lands Directorate, Environment Canada: Ottawa, ON, Canada, 1987; ISBN 978-0-662-15077-0.

32. DUC. Southern Ontario Wetland Conversion Analysis; Ducks Unlimited: Barrie, ON, Canada, 2010; p. 96.

33. Tiner, R.W. Wetland Indicators: A Guide to Wetland Formation, Identification, Delineation, Classification, and Mapping, Second Edition; CRC Press: Boca Raton, FL, USA, 2016; ISBN 978-1-4398-5370-2.

34. ESTR. Mixedwood Plains Ecozone + Evidence for Key Finding Summary; Canadian biodiversity: Ecosystem status and trends 2010, Evidence for Key Findings Summary; Canadian Councils of Resource Ministers: Ottawa, ON, Canada, 2016; p. 157.

35. Haddad, N.M.; Brudvig, L.A.; Clobert, J.; Davies, K.F.; Gonzalez, A.; Holt, R.D.; Lovejoy, T.E.; Sexton, J.O.; Austin, M.P.; Collins, C.D.; et al. Habitat fragmentation and its lasting impact on Earth's ecosystems. Sci. Adv. 2015, 1, e1500052. [CrossRef] [PubMed]

36. Rybarczyk, G.; Wu, C. Bicycle facility planning using GIS and multi-criteria decision analysis. Appl. Geogr. 2010, 30, 282-293. [CrossRef]

37. Malczewski, J.; Rinner, C. Multicriteria Decision Analysis in Geographic Information Science; Advances in Geographic Information Science; Springer: New York, NY, USA, 2015; ISBN 978-3-540-74756-7.

38. Egoh, B.; Rouget, M.; Reyers, B.; Knight, A.T.; Cowling, R.M.; van Jaarsveld, A.S.; Welz, A. Integrating ecosystem services into conservation assessments: A review. Ecol. Econ. 2007, 63, 714-721. [CrossRef]

39. Cromley, R.G.; Huffman, F.T. Modeling Situation Factors Used in MCE Procedures for Raster GIS. Trans. GIS 2006, 10, 239-251. [CrossRef]

40. Nas, B.; Cay, T.; Iscan, F.; Berktay, A. Selection of MSW landfill site for Konya, Turkey using GIS and multi-criteria evaluation. Env. Monit. Assess. 2009, 160, 491-500. [CrossRef]

41. Wood, L.J.; Dragicevic, S. GIS-Based Multicriteria Evaluation and Fuzzy Sets to Identify Priority Sites for Marine Protection. Biodivers. Conserv. 2007, 16, 2539-2558. [CrossRef]

42. Shaker, R.R.; Sirodoev, I.G. Assessing sustainable development across Moldova using household and property composition indicators. Habitat. Int. 2016, 55, 192-204. [CrossRef]

43. Shaker, R.R. Examining sustainable landscape function across the Republic of Moldova. Habitat Int. 2018, 72, 77-91. [CrossRef]

44. White, D.; Fennessy, S. Modeling the suitability of wetland restoration potential at the watershed scale. Ecol. Eng. 2005, 24, 359-377. [CrossRef]

45. Darwiche-Criado, N.; Sorando, R.; Eismann, S.G.; Comín, F.A. Comparing Two Multi-Criteria Methods for Prioritizing Wetland Restoration and Creation Sites Based on Ecological, Biophysical and Socio-Economic Factors. Water Resour. Manag. 2017, 31, 1227-1241. [CrossRef]

46. Horvath, E.K.; Christensen, J.R.; Mehaffey, M.H.; Neale, A.C. Building a potential wetland restoration indicator for the contiguous United States. Ecol. Indic. 2017, 83, 463-473. [CrossRef] [PubMed]

47. Van Lonkhuyzen, R.A.; LaGory, K.E.; Kuiper, J.A. Modeling the Suitability of Potential Wetland Mitigation Sites with a Geographic Information System. Environ. Manag. 2004, 33, 368-375. [CrossRef] [PubMed]

48. Mayer, A.L.; Lopez, R.D. Use of Remote Sensing to Support Forest and Wetlands Policies in the USA. Remote Sens. 2011, 3, 1211-1233. [CrossRef]

49. CCEA, C.C. on E.A. Ecological Regionalization in Canada. Available online: http://ecozones.ca/english/ regionalization.html (accessed on 22 November 2020).

50. Freedman, B.; Hutchings, J.; Gwynne, D.; Smol, J.; Suffling, R.; Turkington, R.; Walker, R.; Bazely, D. Ecology: A Canadian Context; Top Hat: Toronto, ON, Canada, 2014; ISBN 978-0-17-651014-5.

51. Bradford, A. Averting degradation of southern Ontario wetlands due to hydrologic alterations associated with development. Can. Water Resour. J. Rev. Can. Des Ressour. Hydr. 2016, 41, 543-553. [CrossRef]

52. Ahern, F.; Frisk, J.; Latifovic, R.; Pouliot, D. Monitoring Ecosystems Remotely: A Selection of Trends Measured from Satellite Observations of Canada; Canadian Councils of Resource Ministers: Toronto, ON, Canada, 2010; p. 73.

53. OEP. Ontario Population Projections Update, 2019-2046; Ontario Ministry of Finance: Oshawa, ON, Canada, 2020; p. 111.

54. Dahl, T.E.; Johnson, C.E.; Frayer, W.E. Wetlands, Status and Trends in the Conterminous United States, Mid-1970's to Mid-1980's: First Update of the National Wetlands Status Report; US Department of the Interior, Fish and Wildlife Service: Washington, DC, USA, 1991; ISBN 978-0-16-035916-3. 
55. OBC. State of Ontario's Biodiversity 2015 Summary; Ontario Biodiversity: Peterborough, ON, Canada, $2015 ;$ p. 12.

56. ESRI. ArcGIS Desktop 10.7x; Environmental Systems Research Institute: Redlands, CA, USA, 2019.

57. Khalili, K. Comparison of Geostatistical Methods for Interpolation Groundwater Level (Case Study: Lake Urmia Basin). Available online: /paper/Comparison-of-Geostatistical-Methods-for-Level-Lake-Khalili/ e1eba153321e5229d7e42a13b6c424683be56562 (accessed on 2 November 2020).

58. Forsythe, K.W.; Marvin, C.H. Analyzing the Spatial Distribution of Sediment Contamination in the Lower Great Lakes. Water Qual. Res. J. 2005, 40, 389-401. [CrossRef]

59. Mitchell, D.; Forsythe, K.W.; Marvin, C.; Burniston, D. Temporal Trends and Origins of Lake Erie Cadmium Contamination in Relation to Sediment Substrate Type Using Multivariate Kriging Analyses. Int. J. Geospat. Environ. Res. 2019, 6. Available online: https://dc.uwm.edu/ijger/vol6/iss1/3/ (accessed on 1 November 2020).

60. Forsythe, K.W.; Marvin, C.H.; Valancius, C.J.; Watt, J.P.; Aversa, J.M.; Swales, S.J.; Jakubek, D.J.; Shaker, R.R. Geovisualization of Mercury Contamination in Lake St. Clair Sediments. J. Mar. Sci. Eng. 2016, 4, 19. [CrossRef]

61. Atkinson, D.M.; Deadman, P.; Dudycha, D.; Traynor, S. Multi-criteria evaluation and least cost path analysis for an arctic all-weather road. Appl. Geogr. 2005, 25, 287-307. [CrossRef]

62. Antrop, M. The language of landscape ecologists and planners: A comparative content analysis of concepts used in landscape ecology. LAND Landsc. Urban Plan. 2001, 55, 163-173. [CrossRef]

63. Shaker, R.R.; Rybarczyk, G.; Brown, C.; Papp, V.; Alkins, S. (Re)emphasizing Urban Infrastructure Resilience via Scoping Review and Content Analysis. Urban Sci. 2019, 3, 44. [CrossRef]

64. Krippendorff, K. Content Analysis: An Introduction to Its Methodology; Sage: Thousand Oaks, CA, USA, 2019; ISBN 978-1-5063-9566-1.

65. Saaty, T.L. A scaling method for priorities in hierarchical structures. J. Math. Psychol. 1977, 15, $234-281$. [CrossRef]

66. Kangas, J.; Store, R.; Leskinen, P.; Mehtätalo, L. Improving the quality of landscape ecological forest planning by utilising advanced decision-support tools. For. Ecol. Manag. 2000, 132, 157-171. [CrossRef]

67. McPhail, A.K. A Method for Analyzing Historical Wetland Habitat Conditions; Severn Sound Environmental Association: Port McNicoll, ON, Canada, 2004; p. 14.

68. Barbosa, A.M.; Real, R. Applying Fuzzy Logic to Comparative Distribution Modelling: A Case Study with Two Sympatric Amphibians. Available online: https://www.hindawi.com/journals/tswj/2012/428206/ (accessed on 2 November 2020).

69. Goparaju, L.; Tripathi, A.; Jha, C.S. Forest fragmentation impacts on phytodiversity-An analysis using remote sensing and GIS. Curr. Sci. 2005, 88, 1264-1274.

70. Choi, S.; Cha, S. A survey of Binary similarity and distance measures. J. Syst. Cybern. Inform. 2010, 43-48.

71. Jaccard, P. Nouvelles Recherches Sur la Distribution Florale; Rouge: Lausanne, Switzerland, 1908.

72. Birks, H.J.B. Recent methodological developments in quantitative descriptive biogeography. Ann. Zool. Fenn. 1987, 24, 165-177.

73. Tobler, W.R. A Computer Movie Simulating Urban Growth in the Detroit Region. Econ. Geogr. 1970, 46, 234-240. [CrossRef]

74. Getis, A.; Ord, J.K. The Analysis of Spatial Association by Use of Distance Statistics. Geogr. Anal. 1992, 24, 189-206. [CrossRef]

75. Wong, D.W.S.; Lee, J. Statistical Analysis of Geographic Information with ArcView GIS and ArcGIS; Wiley: Hoboken, NJ, USA, 2005; ISBN 978-0-471-46899-8.

76. SC. Census Subdivision (CSD)—Census Dictionary. Available online: https://www12.statcan.gc.ca/censusrecensement/2011/ref/dict/geo012-eng.cfm (accessed on 5 November 2020).

77. ODC. Quaternary Watershed Boundaries-Ontario Data Catalogue. Available online: https://data.ontario.ca/ dataset/quaternary-watershed-boundaries (accessed on 5 November 2020).

78. Zedler, J.B. Wetlands at your service: Reducing impacts of agriculture at the watershed scale. Front. Ecol. Environ. 2003, 1, 65-72. [CrossRef]

79. DeLaney, T.A. Benefits to downstream flood attenuation and water quality as a result of constructed wetlands in agricultural landscapes. J. Soil Water Conserv. 1995, 50, 620-626.

80. Canadian Wildlife Service; Environment Canada. The Federal Policy on Wetland Conservation; Environment Canada: Ottawa, ON, Canada, 1991; ISBN 978-0-662-18940-4. 
81. Rubec, C.D.A.; Hanson, A.R. Wetland mitigation and compensation: Canadian experience. Wetl. Ecol Manag. 2009, 17, 3-14. [CrossRef]

82. ECCC. Evaluation at a Glance: Evaluation of the National Wetland Conservation Fund; ECCC: Toronto, ON, Canada, 2019.

83. USA. North American Wetlands Conservation Act (103 Stat. 1968); NAWCA: Washington, DC, USA, 1989; Volume 103, p. 11.

84. Shaker, R.R.; Aversa, J.; Papp, V.; Serre, B.M.; Mackay, B.R. Showcasing Relationships between Neighborhood Design and Wellbeing Toronto Indicators. Sustainability 2020, 12, 997. [CrossRef]

85. Leitão, A.; Miller, J.; Ahern, J.; McGarigal, K. Measuring Landscapes; Island Press: Washington, DC, USA, 2006; ISBN 978-1-55963-899-9.

Publisher's Note: MDPI stays neutral with regard to jurisdictional claims in published maps and institutional affiliations.

(C) 2020 by the authors. Licensee MDPI, Basel, Switzerland. This article is an open access article distributed under the terms and conditions of the Creative Commons Attribution (CC BY) license (http://creativecommons.org/licenses/by/4.0/). 